\title{
Do Seller Disclosures Affect Property Values? Buyer Information and the Hedonic Model
}

Jaren C. Pope

\begin{abstract}
The hedonic method is widely used to infer the value of environmental amenities that are bundled with real property. The interpretation of hedonic prices as marginal values requires that households are "fully informed." Yet, there is evidence that buyers are often less informed than sellers. A graphical illustration in this study suggests that asymmetric information between buyers and sellers can affect hedonic prices. This intuition is confirmed by a quasi-random experiment that exploits spatial and information discontinuities stemming from a seller disclosure for flood zones. Results suggest a 4\% decline in housing prices in flood zones after disclosures commenced. (JEL Q51, R52)
\end{abstract}

\section{INTRODUCTION}

The hedonic method has played a key role in the evaluation of environmental policy as well as in public litigation over the past five decades. Applied to property values, this revealed preference method has been used in environmental economics to infer the value of a variety of environmental goods and services that can be linked to housing markets. The hedonic method has informed policymakers on such topics as the value of air quality (Ridker and Henning 1967; Smith and Huang 1995), perceived health risks from hazardous waste sites (Kiel and McClain 1995; Gayer, Hamilton, and Viscusi 2000), and the value of open space (Geoghegan, Wainger, and Bockstael 1997). ${ }^{1}$ It has also been used to

\footnotetext{
${ }^{1}$ See Palmquist and Smith (2002) for further discussion on the role of the hedonic method in environmental policy and public litigation as well as Palmquist (2005) for an extensive review of the hedonic method as applied to environmental economics.
}

Land Economics • November 2008 • 84 (4): 551-572 ISSN 0023-7639; E-ISSN 1543-8325

(C) 2008 by the Board of Regents of the University of Wisconsin System inform the public litigation process by providing information for Natural Resource Damage Assessments (Rowe and Schulze 1985). ${ }^{2}$ With the advent of GIS and the increasing availability of housing data, there is reason to believe that the hedonic method will continue to be widely applied to valuation problems in environmental economics.

Despite the extensive use of the hedonic method, there has been debate about the degree to which estimated implicit prices correspond with the preferences of buyers and sellers in housing markets. Much of the discussion in the literature has revolved around the empirical specification of the hedonic price function (Cropper, Deck, and McConnell 1988; Cameron 2006). Related to these functional form issues has been the concern that estimates may suffer from omitted variable bias (Black 1999; Leggett and Bockstael 2000; Chay and Greenstone 2005). However, equally crucial to the

The author is an assistant professor in the Department of Agricultural and Applied Economics at Virginia Tech. The author is especially thankful to V. Kerry Smith for his input into this project and is also grateful for the comments and suggestions provided by Antonio Bento and participants at the AERE Session at the 2007 AEA meetings, Kevin Boyle, Nick Kuminoff, Ray Palmquist, Chris Parmeter, Dan Phaneuf, Arden Pope, Devin Pope, and Wally Thurman. The project was partially supported by the USDA Cooperative State Research, Education, and Extension Service, Hatch project \#135833. The author also gratefully acknowledges funding from the Department of Housing and Urban Development and offers the disclaimer, prepared under grant number $\mathrm{H}$ 21514SG from the Department of Housing and Urban Development, Office of University Partnerships. The points of views or opinions in this document are those of the author and do not necessarily represent the official position or policies of the Department of Housing and Urban Development.

${ }^{2}$ Natural Resource Damage Assessments have been conducted for cases related to the Comprehensive Environmental Response, Compensation, and Liability Act (CERCLA) and the Oil Pollution Act (OPA). 
interpretation of estimated implicit prices as marginal values are the underlying assumptions of the hedonic model. For example, the assumption that both buyers and sellers are "fully informed" is necessary to conclude that housing prices reflect buyers and sellers preferences.

This study extends the debate on the reliability of the hedonic method by analyzing the impact of the full information assumption on estimated implicit prices. Purchasing a house certainly requires time and effort to make an informed choice. There are many structural and locationspecific characteristics to consider for a buyer. There is evidence in the housing market that sellers have lower search costs and are more informed about some housing attributes, such as environmental disamenities, than homebuyers. ${ }^{3}$ Sellers often acquire location-specific information relevant to the house they are selling at low cost by virtue of living there. Recently most states have enacted some form of "seller disclosure" laws, apparently to reduce information asymmetries between buyers and sellers. ${ }^{4}$ These laws not only require sellers to supply their "private" information about the quality of the house, they sometimes also re-provide information that was "publicly available" before the disclosure. Re-providing information that is publicly available directly conflicts with the hedonic model's assumption that buyers are fully informed.

The focus of this study is to better understand the degree to which an information asymmetry between home buyers and home sellers has an impact on estimated implicit prices. Theoretically adapting the hedonic model to allow for costly search and asymmetric information between buyers and sellers is difficult. In this setting, the exact nature and location of the housing price equilibrium cannot be defined or precisely located. Nonetheless, this study

\footnotetext{
${ }^{3}$ An example of one such location specific disamenity where homebuyers appear less informed than sellers is landfills as pointed out in Shulze et al. (1986).

${ }^{4}$ See Lefcoe (2004) for a discussion of mandatory disclosure laws and their history.
}

argues that if sellers are informed about a location-specific disamenity, whereas a fraction of buyers are uninformed, then the standard estimated implicit price will suffer from attenuation bias relative to a "full information" estimate of the disamenity. This argument is justified using intuition from search theory and graphical descriptions of buyers' and sellers' reservation bids and offer curves. The basic logic of the argument is that as the fraction of uninformed buyers in the market increases, sellers are more likely to set a reservation offer that recognizes that uninformed buyers' bids are insensitive to changes in the quality of the attribute. Given this logic, it would be desirable to also provide empirical evidence for the impact of asymmetric information on estimated implicit prices.

Flood zones are an example of a housing disamenity where sellers may be more informed than buyers. In a survey with homeowners who live in federally designated special flood hazard areas conducted by Chivers and Flores (2002), it was found that most homeowners did not learn their house was in a flood zone until after they made a bid on their house. Furthermore, over twothirds of these same respondents said that if they had been more informed about the flood risk and the cost of flood insurance, they would have lowered their bid for the house. Chivers and Flores suggest that lack of buyer information severely hampers the efficiency of the housing market in flood prone areas and conclude that, "obviously there is a need to bridge the information gap between buyers and sellers."

To better ensure that buyers are fully informed about flood risks and other housing attributes, North Carolina instituted a seller disclosure law beginning in 1996 . The seller disclosure can be considered an exogenous change that triggers or induces recognition of this housing attribute by uninformed buyers and therefore can be used to test the attenuating bias of asymmetric information. An identification strategy that exploits the timing of the disclosure also helps to alleviate the persistent concern of omitted variable bias. Using a spatial 
fixed-effects strategy and a limited temporal and spatial sample of houses that bracketed both the timing of the disclosure and the flood zone areas, the estimates generated from hedonic regressions indicate that the disclosure reduced housing prices in FEMA designated flood zones by approximately $4 \%$. Prior to the disclosure, there appeared to be no impact of flood plain designation on housing prices in the area. A "naïve" regression using all of the data, but not taking into account the information shift would have estimated the flood plain impact to be approximately one-half of what was estimated after disclosures began taking place.

These results suggest that asymmetric information between buyers and sellers caused estimated marginal values for flood plains to be attenuated prior to the disclosure. The estimate of the implicit price for the location specific disamenity after the information shock may offer a more accurate measure of the marginal value for flood plains as it reflects choices where buyers were more fully informed. The results contradict what would be predicted by the conventional hedonic model since flood zone information was publicly available prior to the disclosure. Therefore, the results are suggestive that buyer information search constraints are important to the home buying process and the hedonic model.

The remainder of the study will proceed as follows. Section 2 provides background on the hedonic model and describes the possible impact of asymmetric information on the implicit price of an attribute. Section 3 gives some background on flood insurance and the North Carolina disclosure program, as well as describes the study area and data used in the empirical analysis. Section 4 provides a literature review of the impact of flood plains on property values, and outlines an identification strategy for understanding the impact of the disclosure on the implicit price for reducing flood risk. Section 5 describes the results of the hedonic price regressions. Section 6 concludes the study.

\section{ASYMMETRIC INFORMATION AND THE HEDONIC MODEL}

Rosen (1974) is widely credited with developing the theoretical foundation for the interpretation of coefficients in properly specified hedonic price models. $\mathrm{He}$ showed that under ideal conditions an equilibrium price locus "reveals" the marginal values for small changes in each attribute that distinguishes a heterogeneous good such as a house. Figure 1 illustrates the well-known diagram of the hedonic price locus for an amenity $z^{i}$ where the envelope of buyers' bids for the amenity (represented by the $B^{i}$ s) is just tangent to the envelope of sellers' offers (represented by the $O^{i}$ s). In this diagram $P\left(z^{i} \mid z^{* k \neq i}\right)$ represents the hedonic price equilibrium. Since the diagram is presented in two dimensions, all other attributes $k$ are being held constant at their equilibrium levels. Figure 2 presents the analogous diagram for the case of a disamenity $z^{j}$. Although the sellers in Rosen's formulation were profit-maximizing builders of houses, this standard diagram can also be interpreted as reflecting utility-maximizing owners' offers in a market with fixed supply.

The elegant simplicity of the upper envelope of buyers' bids just "kissing" the lower envelope of sellers' offers in these diagrams such that prices reveal buyer and seller preferences, hinges on some key assumptions including: (1) continuity in the levels of attributes, and (2) full information about prices and attributes. Relaxing either of these assumptions will relax the tight correspondence between the envelopes of buyers' maximum bids and sellers' minimum offers. In their paper, Harding, Rosenthal, and Sirmans (2003) showed graphically the impact of relaxing the continuity assumption. Their illustration also applies to relaxing the assumption that prices and attributes are known to all buyers and sellers. ${ }^{5}$ An adaptation of their

\footnotetext{
${ }^{5}$ A similar graphical argument is also made in Kumbhakar and Parmeter (2006).
} 


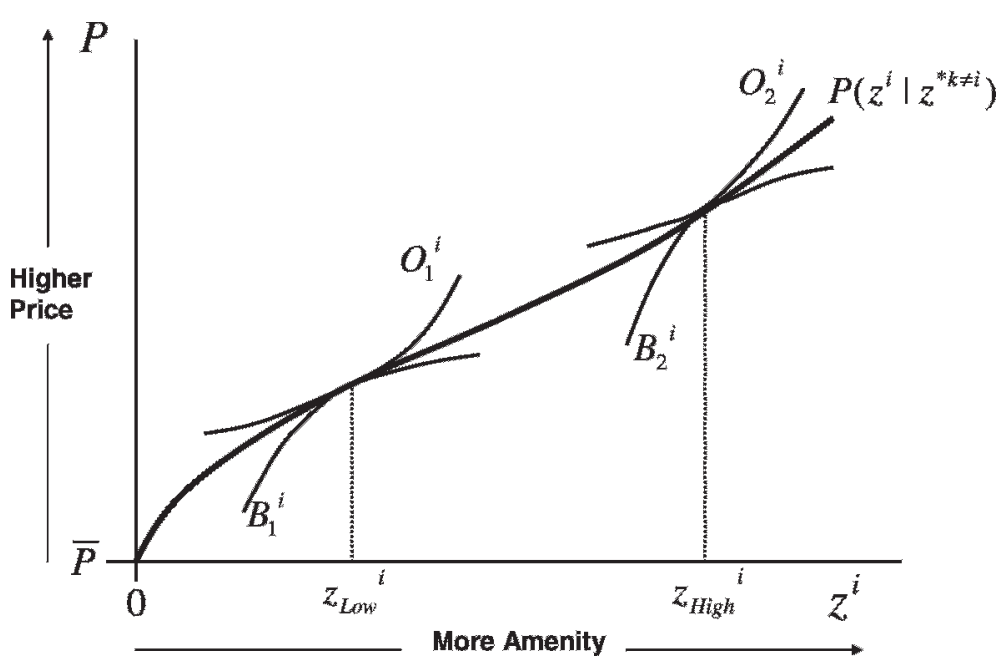

FIGURE 1

Standard Hedonic Diagram of Amenity $j$

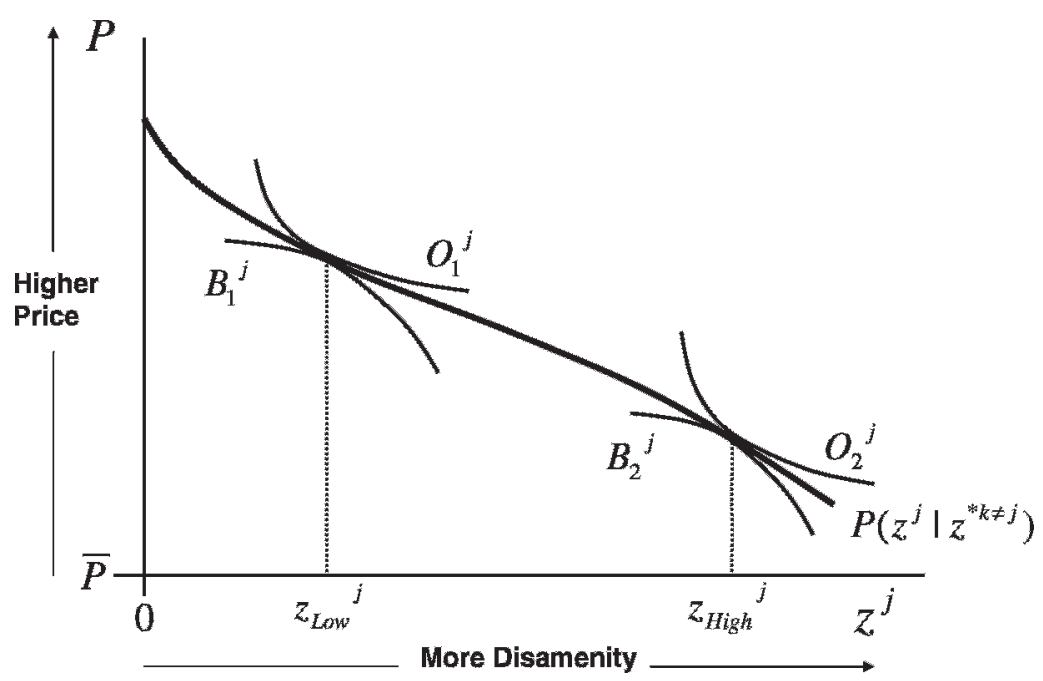

FIGURE 2

Standard Hedonic Diagram of Disamenity

diagram for disamenity $j$ is shown in Figure 3. In this figure, local market power that arises in "thin" housing markets or the search costs from acquiring price information cause an overlap in reservation bid and offer envelopes. ${ }^{6}$ Bargaining and search costs allow for transactions to take place

\footnotetext{
${ }^{6}$ They are now reservation bids and offers because of the uncertainty involved in bargaining and search.
}

anywhere between the maximum reservation bid and minimum reservation offer envelopes (the dots represent transactions occurring between these envelopes). The equilibrium price function now has an error term added to it $(\eta)$ to reflect bargaining and search costs.

If there are no systematic differences in bargaining and search costs between buyers and sellers, such that transactions are 


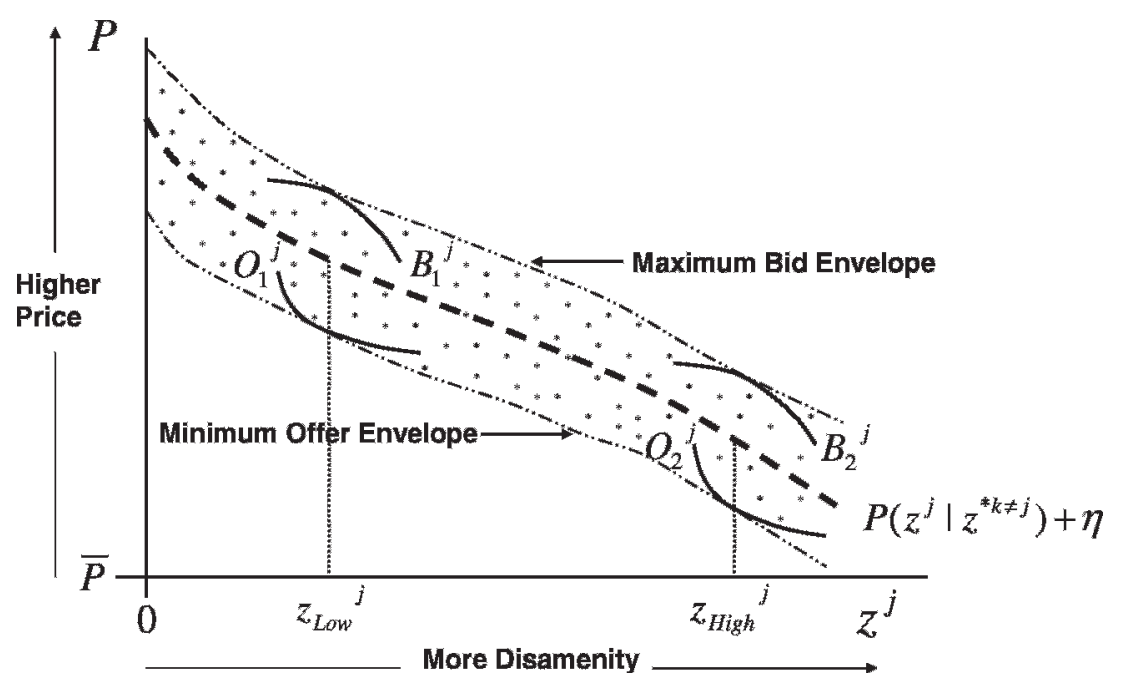

FIGURE 3

INCOMPLETE INFORMATION AND THE HEDONIC

randomly distributed around the hedonic price function of Figure 2, then a consistent estimate of the implicit price and the marginal values of buyers and sellers could be obtained. ${ }^{7}$ However, sellers may have lower search costs for some attributes than homebuyers. Sellers often acquire locationspecific information relevant to the house they are selling at low cost by virtue of living there. Information is also more likely to attract a homeowner's attention because of its locational immediacy. Buyers, on the other hand, are faced with the task of acquiring information for a host of structural and neighborhood characteristics for each house they seriously consider over a short time period. Differences in search costs can leave buyers asymmetrically informed about some housing attributes relative to sellers.

Asymmetric information of this sort is illustrated by a study conducted by Schulze

\footnotetext{
${ }^{7}$ Papers that have looked at the impact of information on the hedonic price function typically assume that real estate agents, mortgage lenders, and other housing institutions maintain symmetry in information between buyers and sellers. See for example McCluskey and Rausser (2003).
}

et al. (1986). Their study compared health risk beliefs of homeowners near a landfill site with expert judgments of the health risk and evaluated these differential risks in a hedonic model. To measure subjective health risks, Schulze et al. interviewed homeowners in the area of their studyneighborhoods in Southern California around a toxic landfill. An unexpected result from the survey was that only $35 \%$ of the survey respondents reported to have been aware of the landfill at the time they purchased their house, even though there was significant coverage in the local media about the landfill and its' potential health impacts over the relevant time period. This is in stark contrast to the $94 \%$ of survey respondents that reported to have become aware of the landfill after buying a home in the area. ${ }^{8}$ The results of this survey illustrate the potential for large disparities in what buyers and sellers know about a

\footnotetext{
${ }^{8}$ In the survey, Schulze et al. (1986) asked homeowners if they were aware of the landfill at the time of purchase and if they were currently aware of the landfill. Thus the percentages they report for awareness at the time of home purchase, and after having lived in the home are generated from the same sample of homeowners.
} 


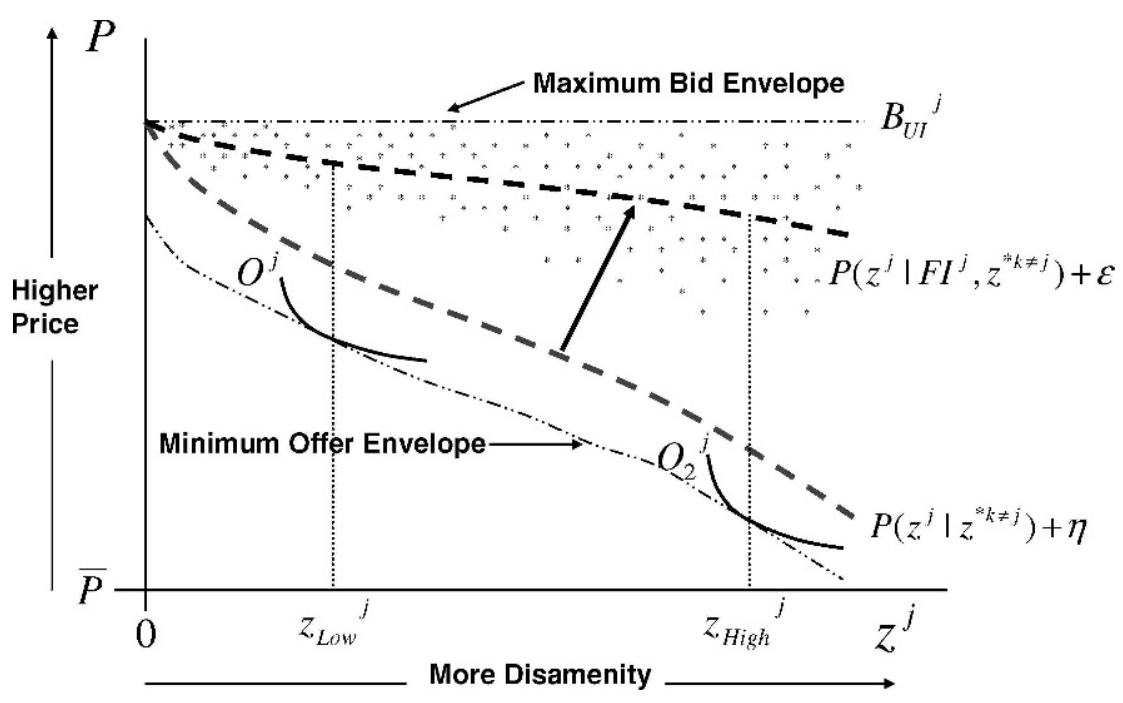

FIGURE 4

Asymmetric Information and the Hedonic

disamenity whose information is considered publicly available. ${ }^{9}$

Figure 4 provides an illustration of the possible impact of asymmetric information between buyers and sellers on the hedonic price function. Here it is assumed that sellers are informed about disamenity $j$, whereas only a fraction of buyers are informed $\left(F I^{j}\right) .{ }^{10}$ Uninformed buyers do not adjust their bids for changes in the level of disamenity $j$. This changes the nature of the maximum reservation bid envelope. The maximum reservation bid for any level of the disamenity will now always come from an uninformed buyer. These bids are represented by the horizontal line labeled $B_{U I}^{j}$. If sellers whose homes are plagued by disamenity $j$ recognize that there exists this fraction of uninformed buyers, then they are likely to adjust their offers conditional on an expectation of uninformed buyers' bids. Sellers with low search costs who can

\footnotetext{
${ }^{9}$ The results also show that housing market institutions such as real estate agents and mortgage lenders do not always "correct" the information asymmetry as is typically assumed in the hedonic literature.

${ }^{10}$ Asymmetric information about a housing attribute is most likely to occur for localized disamenities for which owners of homes without the disamenity are unlikely to disclose that their house is not affected by the disamenity.
}

afford to wait for an uninformed buyer who "overpays" for the disamenity, will set their reservation offers near the uninformed buyers reservation bids. The higher the fraction of uninformed buyers, the more and more attractive it is for sellers to wait for an uninformed buyer to make a bid on the house, and the more attenuated an estimate of the implicit price for disamenity $j$ may be.

The arrow from the $P\left(z^{j} \mid z^{* k \neq j}\right)+\eta$ equilibrium to the $P\left(z^{j} \mid F I^{j}, z^{* k \neq j}\right)+\varepsilon$ equilibrium illustrates the possible attenuating bias from an estimate of buyers' and sellers' marginal values for disamenity $j$ when there is a significant fraction of uninformed buyers. ${ }^{11}$ This movement suggests that under asymmetric information, empirical estimates of the impact of the disamenity on housing prices would under-represent the marginal value of disamenity $j$. The inclusion of the $F I^{j}$ is a reminder that the price equilibrium is now conditional on the fraction of informed buyers in the market when there is asymmetric information.

\footnotetext{
${ }^{11}$ The error terms for the two price functions may differ in their interpretation and so have been labeled differently.
} 
Although the intuition from the graphical analysis above is suggestive of an attenuating bias from asymmetric information, the exact position of this price schedule has not been formally proved. Proving the equilibrium impact of information heterogeneity on a highly differentiated product is difficult and has not been done. Empirical validation of the graphical prediction of an attenuating bias is therefore desirable. An empirical application would require finding an example where information about the housing attribute of focus is publicly available and is arguably known to sellers but may not be known to buyers without effort. An attractive example would also involve an exogenous change that triggers or induces recognition of the feature by buyers. A comparison of marginal implicit price estimates before and after an exogenous information event could provide a basis for gauging the importance of the arguments about asymmetric information developed above. A flood zone disclosure in Wake County, North Carolina, was found to fit these criteria and can be used as a quasirandom information experiment.

\section{BACKGROUND ON DISCLOSURE, STUDY AREA, AND DATA}

\section{Background on Flood Zone Disclosure}

Flooding has caused more economic loss than any other natural hazard in the United States. ${ }^{12}$ During the 1980s, the average annual property loss from flood damage was 3.85 billion dollars. This aggregate loss increased to 6.44 billion dollars per year during the 1990 s. ${ }^{13}$ With other recent large flooding events, it appears flood damages may continue to increase for the current decade. There are two main types of floods: inland stream flooding and coastal flooding. Inland stream flooding accounts for the majority of the economic

\footnotetext{
${ }^{12}$ GAO Report (2003).

${ }^{13}$ Dollar amounts have been adjusted to 2002 dollars. The information was obtained from the National Weather Service at http://www.nws.noaa.gov/oh/hic/ flood_stats/Flood_loss_time_series.shtml.
}

losses, whereas coastal flooding accounts for the majority of deaths. The focus of the empirical application in this study is on inland stream flooding, which is a widespread phenomenon that affects properties throughout the United States.

Private homeowner insurance policies typically do not provide coverage for flooding. This omission is due largely to the fact that private insurance companies, facing adverse selection and an inability to spatially diversify their risks, have found it unprofitable to provide flood insurance services. Historically, as the number of homes being built in flood plains increased over the years, local governments and the federal government began bearing more and more of the social costs related to floods. Those costs included: (1) emergency services costs, (2) loss of taxes due to damaged and lost businesses and homes, and (3) other post-disaster relief spending such as loans, emergency housing, food, and clothing. ${ }^{14}$ Recognizing these costs and the lack of a private market solution, Congress enacted the National Flood Insurance Act (NFIP) in 1968. One of the primary goals of the act was to provide homeowners in participating communities that met certain standards, the option of buying flood insurance. ${ }^{15}$ However, because of low participation rates, the Flood Disaster Protection Act of 1973 was enacted requiring purchase of flood insurance for property owners taking out loans with federally regulated lending institutions.

Since 1973, the NFIP along with the Federal Emergency Management Agency (FEMA), who has responsibility to map the flood zones, has become one of the biggest domestic programs (and liabilities) in the United States. ${ }^{16}$ As of fiscal year 2004, there were approximately 4.5 million flood

\footnotetext{
${ }^{14}$ See King (2005) for more details.

15 A community must adopt the NFIP's minimum floodplain management standards in its local ordinances. They must also have Flood Insurance Rate Maps (FIRM) created by FEMA and use the maps to guide the community's land-use development plan.

${ }^{16}$ This is along with Social Security and Federal Health programs such as Medicare and Medicaid. See King (2005).
} 
insurance policies in over 20,000 participating communities representing approximately 764 billion dollars of insured property. ${ }^{17}$ Yet even with the mandatory insurance requirement, many property owners have been able to drop their policies after purchasing insurance at the time of financing a home. The lenders involved often fail to ensure that insurance is maintained. ${ }^{18} \mathrm{As}$ a result, it appears that potential buyers of homes in flood zones may often be unaware that a house has substantial flood risks and is subject to mandatory flood insurance requirements. Writing before flood insurance became mandatory in 1973, Krutilla (1966) noted that one of the potential benefits of compulsory flood insurance would be that, "premiums proportional to risk and equal to both the private and social cost of flood plain occupance will serve as a rationing device eliminating economically unwarranted uses of flood plain lands on one hand, while not prohibiting uses for which flood plain location has merit on the other hand." Yet for Krutilla's efficiency scenario to take place via the NFIP, buyers need to be informed about the flood risks and insurance premiums for a property they are considering purchasing.

A survey of buyers' knowledge about flood risk and insurance premiums was conducted by Chivers and Flores (2002) in Colorado. They asked homeowners that had recently purchased homes in a FEMA flood zone that required flood insurance: "when did you first learn of the potential flood risk associated with your home?" They found that $8 \%$ learned prior to making an offer, $6 \%$ prior to closing, $60 \%$ during closing, 4\% after moving, $6 \%$ after being flooded, and $16 \%$ at some other time. This survey indicates that most buyers find

\footnotetext{
${ }^{17}$ See the statistics provided at the FEMA website: www.fema.gov/nfip/pcstat.shtm.

${ }^{18}$ In 1994 the Riegel Community Development Regulatory Improvement Act was passed that required mortgage lenders to ensure that flood insurance policies were taken out for homes in certain FEMA flood plain zones. The final regulations were issued in October of 1996. Since this time, period participation rates in NFIP have risen but it does not appear that there is anywhere near full compliance (e.g., King 2005).
}

out about flood risk and insurance premiums during closing, well after they have made an offer on a house. This is likely due to buyers facing high search and attention costs for learning about some spatial attributes of homes when home buying decisions are made over a short time horizon. Chivers and Flores also note that it is very difficult for buyers who learn this information during closing to back out of the offer because they face intense pressure from the other parties involved (real estate agents, sellers, mortgage lenders, etc.) who have a financial stake in assuring the transaction is completed.

The results from this survey are quite striking since the information about flood insurance rates and the maps designating flood zones are publicly available. The survey suggests that when faced with the complexity of the home-buying decision; buyers may not fully consider the flood plain attribute of a house. ${ }^{19}$ Furthermore, it suggests that the housing institutions have incentives not to provide buyers with the flood zone information early on in the home buying process because it may affect the buyer's purchase decision, imposing unwanted costs on the housing institutions. ${ }^{20}$ Sellers, on the other hand, are likely better informed about flood risk after living in the house for a time because of information given them by neighbors or local government. They may also be better informed or have more accurate perceptions of the importance of flood risk for their property due to observing floods near their homes. However, the influence of previous flooding on seller's information and perceptions of flood risk will depend on the frequency of flooding in the area.

\section{Study Area}

Wake County, North Carolina, is the geographic setting for the analysis in this

\footnotetext{
${ }^{19}$ See Pope (2008) for another example where buyers appear to be less than fully informed for an environmental disamenity.

${ }^{20}$ For lenders this suggests that the value of completing the transaction overrides the default risk cost.
} 
study. Approximately $44 \%$ of the land in the county is forest, $32 \%$ developed residential areas, $12 \%$ agriculture, $8 \%$ miscellaneous other uses, and $4 \%$ water surface area. The county lies between North Carolina's coastal zone to the east and the "piedmont uplands" to the west. The lowest point in the county is 160 feet above sea level whereas the highest point is 540 feet above sea level. Approximately $80 \%$ of the county is drained by the Neuse River and its tributaries. The other $20 \%$ of the county is drained by the tributaries of the Cape Fear River.

As with other inland stream networks throughout the United States, there are periodic floods that occur in Wake County. Two of the most severe flooding episodes occurred when Hurricane Fran and Hurricane Floyd passed through the area on September 5, 1996 and September 16, 1999, respectively. ${ }^{21}$ However, flooding also occurs when there is substantial rainfall in the area over a short period of time. Unlike in coastal areas, it is very difficult to visually determine whether or not a house lies in a flood plain. Therefore one must rely primarily on FEMA mapping information to determine flood risk for a given house. ${ }^{22}$

Recognizing the complexity and cost of information acquisition to buyers in the real estate market, the state of North Carolina and other states have recently decided to make seller disclosure of flood plain information and other housing attributes mandatory. In 1995, North Carolina General Statute 47E known as the "Residential Property Disclosure Act," was passed requiring owners of residential real estate to provide prospective buyers with a property disclosure statement after January 1, 1996. ${ }^{23}$ The last of 20 questions on the disclosure form that sellers were required to provide buyers was the question "do you

\footnotetext{
${ }^{21}$ The timing of Hurricane Fran in relation to the information shock used in this study is important and will be discussed in Section 3 .

${ }^{22}$ This comes from personal communication with real estate agents in the county.

${ }^{23}$ There are some exempted residential properties such as those sold for the first time and those that are leased with an option to purchase.
}

know of any FLOOD HAZARD or that the property is in a FEDERALLY-DESIGNATED FLOOD PLAIN?" (Capitalized words are the same as in the disclosure). This disclosure offers the potential for a quasi-random experiment to identify the impact of the release of information on flood plain zones on the selling prices of houses in these zones.

It does not appear that sellers knew in advance about the residential disclosures that would be required of them. A search of the primary newspaper in the region found no articles describing the residential property disclosure prior to its implementation. ${ }^{24}$ This suggests that from the perspective of buyers and sellers that the seller disclosure was an exogenous shock to their decision environment. Thus sellers whose houses were located in a flood plain were likely unable to put their house on the market "early" to avoid the disclosure.

Buyers who failed to receive a disclosure statement before making their offer on a house after January 1, 1996 have the opportunity to cancel the contract and receive a refund for their deposited money. Conversations with real estate agents in Wake County, suggests that the disclosure is in fact given before an offer is made. Furthermore, it appears to be the convention in Wake County to provide the disclosure to a buyer when they visit the house for the first time with their agent.

As was noted in the introduction, it was possible for buyers to obtain the FEMA flood zone designation and insurance premium information on their own without the aid of this disclosure. The primary ways of doing this was by contacting their mortgage lender or by looking for the information on the surveyor's map of the property. But as suggested by the survey in Chivers and Flores (2002), as well as in conversations with the real estate agents in the area, many buyers fail to make use of these publicly available resources.

\footnotetext{
${ }^{24}$ Electronic searches in The News and Observer were conducted for the two years prior to the implementation of the residential disclosure.
} 


\section{Data Used in the Analysis}

There are three primary datasets used in the analysis. The first is a dataset of singlefamily housing transactions that overlap the beginning of the seller disclosures on January 1, 1996, in Wake County, North Carolina. This data contain a detailed set of structural and neighborhood characteristics derived from the Wake County Revenue Department, The U.S. Census Bureau, and other GIS shapefiles at the county level. Only transactions that occurred between January 1, 1995 and September 5, 1995 and transactions occurring between January 1, 1996 and September 5, 1996 are used for reasons to be detailed in Section 4.

The second dataset is a GIS shapefile of the FEMA flood zone designations. FEMA issues flood maps for each county that participates in the NFIP. For Wake County, there are two primary flood designations that are used in the analysis. Houses in AE zones are those that FEMA has determined have a $1 \%$ or greater annual probability of flooding. ${ }^{25}$ Houses in X500 zones are those that FEMA has determined have between $0.2 \%$ and $1 \%$ annual probability of flooding. These flood zone designations were spatially matched to the houses falling in these zones and dummy variables labeled "zoneAE" and "zoneX500" were created. Figure 5 shows these zones in relation to the housing transactions in Wake County. The third dataset provides information on the major hydrologic units in the county that are of course related to the flood zone areas. Using this dataset the distance from each house to the edge of the nearest major stream or lake was calculated. This new variable, which was named "hydro_ft," will be used to help control for the amenity affect of water bodies in the area.

Table 1 provides descriptions and summary statistics for the housing variables

\footnotetext{
${ }^{25}$ There are also a small number of houses that fall in FEMA designated A zones. These are similar to the AE zones in that they have a similar probability of flooding. In the analysis these zones are combined with the AE zone designation.
}

used in the analysis. ${ }^{26}$ The average house in the dataset was approximately ten years old, had two-and-a-half baths, and sold for approximately $\$ 150,000$. Notice that approximately $1.2 \%$ of houses (178 observations) transacted occurred in an $\mathrm{AE}$ flood zone and less than $1 \%$ in the X500 zone (68 observations). 27 "post1996" in Table 1 is a dummy variable equal to 1 for all houses transacted from January 1, 1996 to September 5, 1996. Approximately $53 \%$ of the transactions in the dataset took place during this time period. Dummy variables were also created for two different census neighborhood designations - block groups and census tracts - but are omitted from Table 1 because of space constraints.

\section{IDENTIFICATION STRATEGY FOR THE HEDONIC}

\section{Previous Flood Plain Hedonic Literature}

There is a small body of research that has examined the impact of flood plain designation on housing prices. $^{28}$ One would expect there to be a price discount associated with a house being located in a flood plain relative to comparable houses that are not located in a flood plain. Nonetheless, the available studies provide mixed results. As was suggested by Chivers and Flores (2002), one reason for these findings is incomplete information about flood risks and insurance premiums. Two recent articles by Bin and Polasky (2004) and Hallstrom and Smith (2005) have explored whether or not flooding events caused by hurricanes convey this needed information to buyers.

In their study, Bin and Polasky used Hurricane Floyd as a quasi-random exper-

\footnotetext{
${ }^{26}$ The block-group and census tract dummies have been excluded and a few of the listed variables will be explained in Section 4.

${ }^{27} 101$ of the AE observations and 44 of the X500 observations occur in the post-disclosure time period.

${ }_{28}$ Early examples include Muckleston (1983), Holway and Burby (1990), Speyrer and Ragas (1991), and Tobin and Montz (1994).
} 


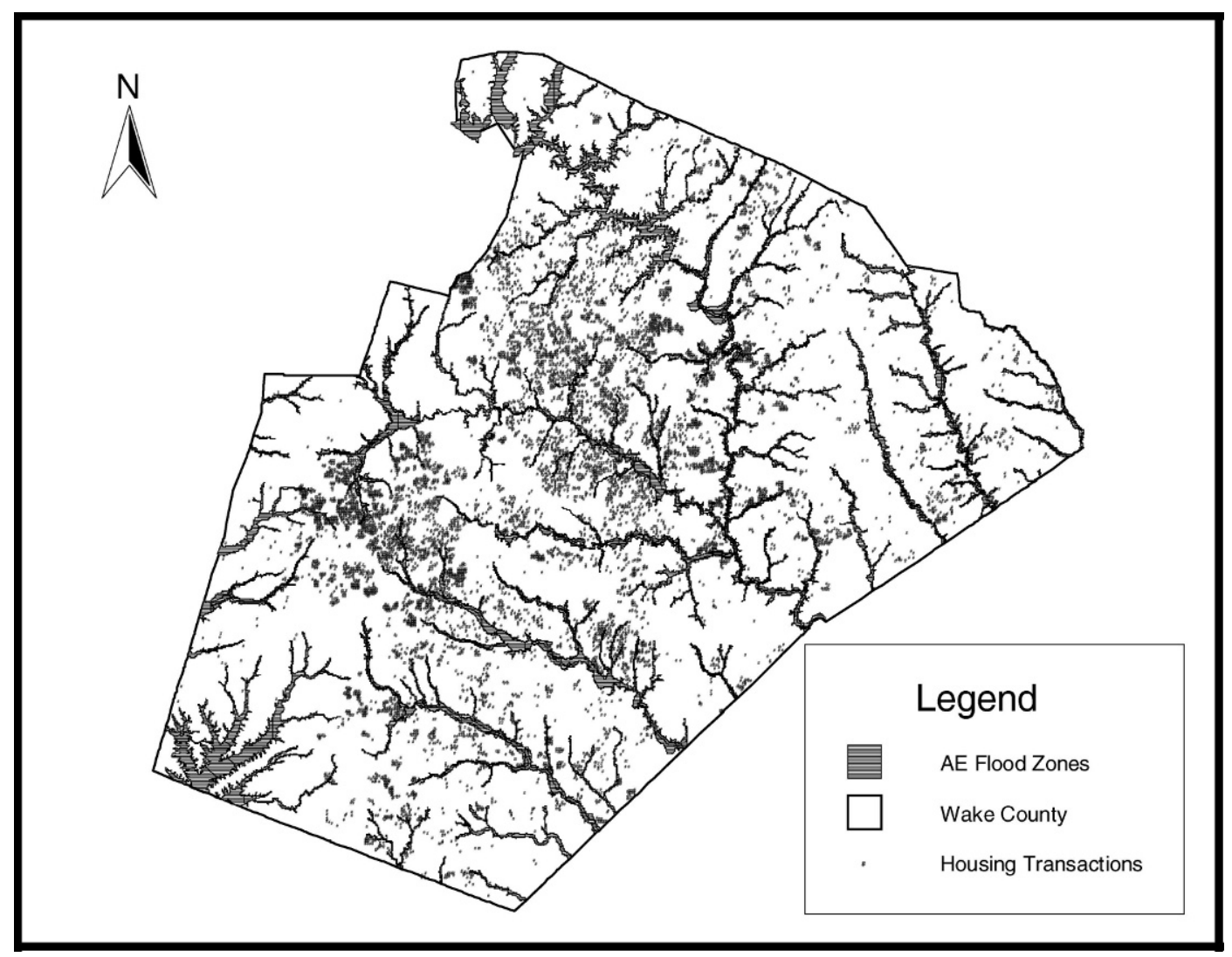

FIGURE 5

Flood Zones and Housing Transactions in Wake County, North Carolina

iment. Hurricane Floyd caused substantial flooding in Pitt County, North Carolina, in September, 1999. Using data on singlefamily residential sales between 1992 and 2002 in the county, Bin and Polasky statistically compared houses in FEMAdesignated flood zones before and after Hurricane Floyd using hedonic price regressions. The results from these regressions suggested a price discount for houses located in flood zones. They also found that this price discount increased substantially after Hurricane Floyd.

While their analysis takes advantage of the potential for a quasi-random experiment provided by nature (which is presumably exogenous), there may be confounders to their identification strategy. Bin and Polasky's primary regression specification takes the following form,

$$
\begin{aligned}
& \text { lprice }=b+\boldsymbol{\alpha} \text { Structural }+\boldsymbol{\varphi} \text { Townships } \\
& +\psi \text { Distances }+\theta \text { Flood } \\
& + \text { SFloyd }+\omega \text { Flood } * \text { Floyd }+\varepsilon
\end{aligned}
$$

where "lprice" is the log of the housing transaction prices deflated by a consumer price index over the 10-year time period; "Structural" is a set of structural characteristics of houses in the sample; "Townships" are 15 dummy variables for the townships in the county; "Distances" are distances to various neighborhood features, including nearest creek or stream; "Flood" indicates if a house is in a flood zone; "Floyd" indicates if the house sold after Hurricane Floyd; and "Flood*Floyd" in- 
TABLE 1

Summary Statistics $(N=15,514)$

\begin{tabular}{|c|c|c|c|c|c|c|}
\hline Variable & Description & Mean & Median & Std. Dev. & Min. & Max. \\
\hline lprice & Log of sale price of property & 11.93 & 11.91 & 0.43 & 9.90 & 14.15 \\
\hline age & Age of house in years & 9.45 & 3 & 14.54 & 0 & 98 \\
\hline baths & Number of bathrooms & 2.45 & 2.50 & 0.69 & 1 & 8 \\
\hline acreage & Lot size in acres & 0.50 & 0.30 & 1.01 & 0.03 & 75.66 \\
\hline regheatarea & Main heated living area in sq. $\mathrm{ft}$. & $1,941.58$ & 1,800 & 725.02 & 400 & 7,593 \\
\hline detgarage & Detached garage dummy & 0.03 & 0 & 0.18 & 0 & 1 \\
\hline fireplaces & Number of fireplaces & 0.89 & 1 & 0.37 & 0 & 3 \\
\hline deck & Deck area in sq. $\mathrm{ft}$. & 172.30 & 152 & 150.97 & 0 & 1,486 \\
\hline sewer & Sewer availability dummy & 0.80 & 1 & 0.40 & 0 & 1 \\
\hline flordum 1 & Hardwood floors dummy & 0.10 & 0 & 0.29 & 0 & 1 \\
\hline scrporch & Screened porch area in sq. ft. & 18.41 & 0 & 60.17 & 0 & 904 \\
\hline walldum1 & Brick walls dummy & 0.12 & 0 & 0.32 & 0 & 1 \\
\hline atticheat & Attic heated area in sq. ft. & 48.01 & 0 & 153.64 & 0 & $1,875.33$ \\
\hline bsmtheat & Basement heated area in sq. $\mathrm{ft}$. & 51.78 & 0 & 209.75 & 0 & 4,788 \\
\hline garage & Garage area in sq. ft. & 290.85 & 364 & 255.35 & 0 & 1,440 \\
\hline poolres & Pool dummy & 0.01 & 0 & 0.11 & 0 & 1 \\
\hline bsmtdum 1 & Full basement dummy & 0.05 & 0 & 0.22 & 0 & 1 \\
\hline bsmtdum2 & Partial basement dummy & 0.07 & 0 & 0.25 & 0 & 1 \\
\hline encporch & Enclosed porch area in sq. ft. & 4.38 & 0 & 31.74 & 0 & 848 \\
\hline opnporch & Open porch area in sq. $\mathrm{ft}$. & 64.13 & 35 & 83.89 & 0 & 1,145 \\
\hline condadum & House of "A" condition dummy & 0.07 & 0 & 0.25 & 0 & 1 \\
\hline condcdum & House of " $C$ " condition dummy & 0.03 & 0 & 0.16 & 0 & 1 \\
\hline condddum & House of " $\mathrm{D}$ " condition dummy & 0.00 & 0 & 0.06 & 0 & 1 \\
\hline perc_no 1990 & Percentage non-white & 17.10 & 13.06 & 15.44 & 0 & 100 \\
\hline medianvalu $\sim \mathrm{t}$ & Median house values & $149,196.10$ & 138,340 & $51,689.62$ & 30,350 & 548,000 \\
\hline medttw_int & Median time to work & 22.62 & 22 & 4.07 & 12 & 35 \\
\hline perc_under $\sim \mathrm{t}$ & Percentage of population under 18 & 26.69 & 27.88 & 5.05 & 2.71 & 49.21 \\
\hline perc_owner $\sim \mathrm{t}$ & $\begin{array}{l}\text { Percentage of owner-occupied } \\
\text { housing }\end{array}$ & 72.25 & 77.92 & 16.81 & 7.58 & 95.65 \\
\hline nearestpark & Distance to nearest park & 4.36 & 3.42 & 2.93 & 0.70 & 18.20 \\
\hline nearestsc & Distance to nearest shopping center & 7.89 & 6.97 & 4.81 & 0.41 & 25.68 \\
\hline taxrate & Property tax rate for area & 0.39 & 0.54 & 0.25 & 0 & 0.64 \\
\hline post1996 & $\begin{array}{l}\text { (See Section 3, Data Used in the } \\
\text { Analysis) }\end{array}$ & 0.53 & 1 & 0.50 & 0 & 1 \\
\hline zoneAE_dum & In AE flood zone dummy & 0.0115 & 0 & 0.11 & 0 & 1 \\
\hline zoneX500_dum & In X500 flood zone dummy & 0.0044 & 0 & 0.07 & 0 & 1 \\
\hline zoneAE_post & In $\mathrm{AE}$ zone and sold with disclosure & 0.0065 & 0 & 0.08 & 0 & 1 \\
\hline zoneX500_post & In X500 zone and sold with disclosure & 0.0029 & 0 & 0.05 & 0 & 1 \\
\hline new_sale ${ }^{-\mathrm{r}}$ - & $\begin{array}{l}\text { (See Section 3, Data Used in the } \\
\text { Anavlysis) }\end{array}$ & 0.29 & 0 & 0.45 & 0 & 1 \\
\hline hydro_dist & $\begin{array}{l}\text { (See Section 3, Data Used in the } \\
\text { Analysis) }\end{array}$ & 0.10 & 0 & 0.18 & 0 & 0.98 \\
\hline
\end{tabular}

dicates houses in a flood zone that sold after Hurricane Floyd. ${ }^{29}$ Also, $\varepsilon$ is an error term; $\beta, \theta, \delta$, and $\omega$ are parameters to be estimated; and $\boldsymbol{\alpha}$ and $\boldsymbol{\varphi}$ represent vectors of parameters to be estimated.

A concern with Bin and Polasky's identification strategy is that it provides limited

\footnotetext{
29 The distance to nearest creek or stream variable was used to distinguish the amenity affect of creeks and streams from the flood risk affect on housing prices.
}

temporal control. Instead of including dummy variables to control for unobserved year specific events, housing prices were deflated using an unreported consumer price index. One concern is that omitted trends or other events correlated with the timing of the hurricane over this ten-year period may lead to violations of the key identifying assumption that is central to their measure of the impact attributed to the flood risk information conveyed by Floyd. 
Another potential confounder is that after the substantial flooding caused by the hurricane, buyers are likely to respond to flood-damaged houses and this would also be reflected in the information impact estimates if unaccounted for in the identification strategy.

Hallstrom and Smith (2005) use Hurricane Andrew and a different identification strategy to estimate the impact of the risk information conveyed by the hurricane on housing prices. Hurricane Andrew, one of the strongest hurricanes ever to hit the United States, passed through the lower part of the Florida panhandle in 1992. The areas directly hit by the hurricane experienced significant damage. Lee County, Florida, just missed being hit by the storm. For approximately 20 years prior to Andrew, the Florida Gulf coast which includes Lee County had had below normal hurricane activity. Hallstrom and Smith hypothesized that although not hit directly, the housing market in Lee County might adjust after observing the devastation of Hurricane Andrew in nearby counties.

Using a housing database of transactions occurring between 1993 and 2000 that also provided each house's previous transaction, Hallstrom and Smith were able to construct a set of price differences for these houses and conduct a repeat sales analysis. ${ }^{30} \mathrm{By}$ exploiting the variation in the timing of the bracketed housing prices, they estimated that the information acquired by buyers and sellers in the housing market in Lee County from Hurricane Andrew lead to a $19 \%$ decline in housing prices in FEMA flood zones. Although their identification strategy avoids some of the temporal- and damage-related issues of Bin and Polasky, it does rely on the assumption that there were no other omitted trends or events that might drive any difference in flood plain housing prices otherwise attributed to Hurricane Andrew over a very lengthy time

\footnotetext{
${ }^{30}$ One advantage of the repeat-sales approach in this context is that the amenity affects of the coast and the risk affects from floods can be more clearly separated.
}

period. ${ }^{31}$ As will be seen, the identification strategy in this paper relies on a much shorter time horizon to better eliminate the concern for time-inconsistent preferences and other temporal confounders. Also given the nature of the seller disclosure, this study attempts to identify the impact of buyer information on the implicit price of flood zones rather than information given to both buyers and sellers.

\section{Initial Identification Strategy}

The strategy to identify the impact of flood plain disclosure on housing prices relies on two key sources of variation. The first is a discrete temporal shift in flood plain information that occurred when the NC Residential Disclosure Statement began to be used on January 1, 1996. The second source of variation is spatial variation in flood risk derived from the FEMA flood plain map in Wake County that identifies areas where sellers are required to provide flood plain disclosure. Using these two sources of variation together with the housing dataset, a simple fixed-effects estimation strategy using a semi-log specification for the price function yields equation [2],

$$
\begin{aligned}
\text { lprice }= & \beta+\boldsymbol{\alpha} \text { Structural }+\boldsymbol{\varphi} \text { Neighborhood } \\
& +\delta \text { Postdisclosure }+\boldsymbol{\omega S \text { Spatial_dums }} \\
& + \text { OZoneAE_dum }+\gamma \text { ZoneX500_dum } \\
& +\lambda \text { ZoneAE_post }+\psi \text { ZoneX500_post } \\
& +\varepsilon,
\end{aligned}
$$

where the "Structural," "Neighborhood," and "Zone_" variables are defined as in Table 1; "Postdisclosure" is a dummy variable designating houses that sold after January 1, 1996; "Spatial_dums" are dummy

\footnotetext{
${ }^{31}$ Hallstrom and Smith dropped houses whose first sale occurred before 1982 from their sample. This suggests that their housing dataset is composed of transactions that occurred between 1982 and 2000. Although they included two time trends (trend since hurricane and trend between sales), whether or not the hedonic is stable or if there are other temporal confounders not explicitly controlled for in their analysis that occur during this 18year window are concerns for their identification strategy.
} 
variables for spatial neighborhoods such as census tracts or block groups; $\varepsilon$ is an error term; $\beta, \delta, \theta, \gamma, \lambda$, and $\psi$ are parameters to be estimated; and $\boldsymbol{\alpha}, \boldsymbol{\varphi}$, and $\boldsymbol{\omega}$ represent vectors of parameters to be estimated. ${ }^{32}$

In experimental terminology, houses in the AE flood plain zone have been "treated" by the disclosure. Houses in the X500 flood plain zone likely received no disclosure, but still have flood risk and therefore act as a potentially interesting comparison group. ${ }^{33}$ Relating these zones to the graphical depiction of the impact of asymmetric information on the implicit price for a disamenity $j$ in Figure 4, the AE zone is like the $z_{H i g h}^{j}$ (high amount of disamenity), whereas the X500 zone is like the $z_{\text {Low }}{ }^{j}$ (low amount of disamenity). Other houses in the county outside of the flood risk zones (but perhaps near streams and lakes) serve as the primary control group. Using the estimating equation above, the coefficient on "ZoneAE_post" (houses in the AE zone that sold after disclosures began) is intended to provide estimates of the impact of the flood plain disclosure on housing prices relative to houses in the X500 zone and other houses in the county.

\section{Identification Strategy that Controls for Known Confounding Influences}

As discussed in Meyer (1995) there is always the prospect for confounders in applying the quasi-random experiment methodology. Omitted variables bias can arise from both the time and space dimensions. One confounding temporal event that occurred in Wake County that likely affected both the housing market and perceptions about flood risks was Hurri-

\footnotetext{
${ }^{32}$ The semi-log specification is used for consistency with the previous literature and because Cropper, Deck, and McConnell (1988) found through simulations of the hedonic price function that in situations where omitted variable bias is a concern, simpler functional forms such as the linear and semi-log forms estimated the marginal attribute prices most accurately.

33 "Being in a FEMA flood zone" as asked by the North Carolina residential disclosure statement is a designation typically given only the $\mathrm{A}$ and $\mathrm{AE}$ zones, not the X500 zone.
}

cane Fran. Hurricane Fran passed directly over the area on September 5, 1996, with wind gusts between 80 and $90 \mathrm{mph}$ and with over 10 inches of rain for most of the county. This storm caused substantial damage to developed and undeveloped properties throughout the area. In fact, there were over 900 million dollars (in 1996 dollars) of reported damage to residential and commercial property due to the hurricane in the county.

It seems reasonable that homes in flood plain zones were most likely to have been damaged by the severe flooding caused by the hurricane. Without any record of which homes received structural damage from floods, this could potentially bias estimates generated from equation [2] if the "Postdisclosure" time period were to overlap September 5, 1996. The hurricane also acts as another type of information treatment that could confound the disclosure treatment. To avoid these confounding influences of Hurricane Fran, one could limit the analysis to a symmetric set of housing transactions that occurred between January 1, 1995 and September 5, 1995 (predisclosure time period) and transactions occurring between January 1, 1996 and September 5, 1996 (post-disclosure time period). ${ }^{34}$ This sample restriction avoids the confounding influence of the hurricane and it may also eliminate other potential temporal confounders that could affect analyses utilizing a larger temporal window (e.g., Hallstrom and Smith 2005).

Another confounder, highlighted in the Bin and Polasky (2004) study, is the amenity effects of proximity to streams and lakes. Thus location in a flood plain may actually partially proxy for this amenity. To avoid a bias due to this possibility, the major hydrologic units in the county were obtained and the linear distance from each house to the nearest major lake or stream was calculated. Because the benefits associated with being near streams and

\footnotetext{
34 January 1, 1995-September 5, 1995 are used instead of May 1, 1995-January 1, 1996 to control for seasonal variation in housing prices.
} 
lakes likely dissipate the further the location of a house, the function given in equation [3] was used to control for proximity effects for the house in relation to streams and lakes:

$$
\text { Hydro_dist }=\max \left[1-\left(d / d_{\max }\right)^{1 / 2}, 0\right],
$$

where $d$ is distance in miles and $d_{\max }$ is a benefit cutoff point set to one-quarter mile for this application. This function creates a convex index between zero and one.

Another potential omitted variable problem may occur if for some reason the type of housing sold during the pre-disclosure and post-disclosure time periods differed substantially. This source of error is also potentially important because housing types may be correlated with other structural disclosures included on the residential disclosure form. A confounder of this type might be new houses built in flood plain zones during the time period included in the dataset. If there is something unique about this new housing stock built in flood zones relative to the "control" houses over this time period, this change in the housing stock could lead to misinterpreting the effects attributed to flood plains. To avoid this bias, a dummy variable was created for houses that sold in the same year that they were built. Although it is possible that houses sold more than once in the year after they were built, this should act as a reasonable proxy for newly built homes.

Table 2 provides summary statistics of the structural and neighborhood variables for houses inside the AE zone and outside of the AE zone for the pre- and postdisclosure time periods. Although housing in the AE zone is on average slightly smaller and less expensive, there do not appear to be any major changes across the pre- and post-disclosure time periods. To test this more formally, a multinomial logit regression was performed on the three main sample types: (1) housing transacted inside the AE zone before the disclosure, (2) housing transacted inside the AE zone after the disclosure, and (3) housing transacted outside of the AE zone. Included in the regression were the primary structural characteristics commonly used in hedonic analyses and the omitted category was sample type (3) above.

Table 3 reports the results of the regression. Columns (1) and (2) correspond with sample types (1) and (2) above. Column (3) reports the results of Chi-squared tests for differences between the models in columns (1) and (2). It appears that houses in the AE zone have larger acreages relative to houses outside the AE zone. Also, houses inside the AE zone transacted after the disclosure have more bathrooms and smaller garage space and this is statistically different from sample (1), as suggested by the chi-squared tests. However, as long as there is sufficient variation in baths and garage space in the full sample of transactions to identify their marginal impacts, these differences should pose no serious problems to the analysis. An overall test of differences between models (1) and (2) is not significant at the $5 \%$ level. There appears to be no difference among the three samples for the "new_sale" variable. This result suggests that the concern about changes in housing composition do not appear to be warranted.

Equation [2] can be updated to include the variables used to control for spatial influences and to restrict the time interval to the year before and after disclosures began taking place in the following way,

$$
\begin{aligned}
\text { lprice }= & \beta+\boldsymbol{\alpha} \text { Structural }+\boldsymbol{\varphi} \text { Neighborhood } \\
& +\delta \text { Post1996 }+\boldsymbol{\omega} \text { Spatial_dums } \\
& + \text { OZoneAE_dum }+\gamma \text { ZoneX500_dum } \\
& +\lambda \text { ZoneAE_post }+\psi \text { ZoneX500_post }, \\
& +\chi \text { New_sale }+\vartheta \text { Hydro_dist }+\varepsilon,
\end{aligned}
$$

where "post1996" is a dummy variable for houses that transacted between January 1, 1996 and September 5, 1996; "new_sale" is a dummy variable for new housing; and "hydro_dist" is the distance measure described by equation [3].

Although the empirical specification in equation [4] represents a detailed analysis of potential unrelated features varying in time and space that could bias estimates, 
TABLE 2

Comparison of Housing Characteristic Means Inside and Outside of ZoneAE Before and After Disclosure

\begin{tabular}{|c|c|c|c|c|c|c|}
\hline Variable & $\begin{array}{l}\text { Outside } \\
\text { ZoneAE }\end{array}$ & $\begin{array}{c}\text { Inside } \\
\text { ZoneAE }\end{array}$ & $\begin{array}{l}\text { Pre-Outside } \\
\text { ZoneAE }\end{array}$ & $\begin{array}{c}\text { Pre-Inside } \\
\text { ZoneAE }\end{array}$ & $\begin{array}{c}\text { Post-Outside } \\
\text { ZoneAE }\end{array}$ & $\begin{array}{c}\text { Post-Inside } \\
\text { ZoneAE }\end{array}$ \\
\hline price & $152,580.87$ & $142,573.08$ & $150,234.10$ & $132,280.51$ & $154,673.23$ & $150,953.93$ \\
\hline lprice & 11.94 & 11.87 & 11.92 & 11.79 & 11.95 & 11.92 \\
\hline age & 9.43 & 11.04 & 9.38 & 13.96 & 9.46 & 8.82 \\
\hline baths & 2.45 & 2.41 & 2.46 & 2.21 & 2.45 & 2.56 \\
\hline acreage & 0.50 & 0.75 & 0.51 & 0.71 & 0.50 & 0.78 \\
\hline regheatarea & $1,942.90$ & $1,828.32$ & $1,947.00$ & $1,703.21$ & $1,939.02$ & $1,923.69$ \\
\hline detgarage & 0.03 & 0.02 & 0.03 & 0.01 & 0.03 & 0.02 \\
\hline fireplaces & 0.89 & 0.85 & 0.90 & 0.83 & 0.89 & 0.87 \\
\hline deck & 172.23 & 178.22 & 174.28 & 189.60 & 170.38 & 169.55 \\
\hline sewer & 0.80 & 0.81 & 0.79 & 0.84 & 0.80 & 0.78 \\
\hline flordum1 & 0.10 & 0.18 & 0.10 & 0.22 & 0.09 & 0.15 \\
\hline scrporch & 18.43 & 16.93 & 18.57 & 22.45 & 18.24 & 12.71 \\
\hline walldum1 & 0.12 & 0.20 & 0.12 & 0.21 & 0.11 & 0.19 \\
\hline atticheat & 47.81 & 65.80 & 47.65 & 60.71 & 48.22 & 69.68 \\
\hline bsmtheat & 51.70 & 58.88 & 55.34 & 70.42 & 48.45 & 50.09 \\
\hline garage & 291.46 & 238.88 & 289.20 & 229.31 & 292.90 & 246.18 \\
\hline poolres & 0.01 & 0.03 & 0.01 & 0.04 & 0.01 & 0.02 \\
\hline bsmtdum1 & 0.05 & 0.11 & 0.05 & 0.14 & 0.05 & 0.08 \\
\hline bsmtdum2 & 0.07 & 0.06 & 0.07 & 0.04 & 0.06 & 0.08 \\
\hline encporch & 4.39 & 3.33 & 5.02 & 4.81 & 3.81 & 2.21 \\
\hline opnporch & 64.05 & 70.84 & 62.74 & 59.30 & 65.42 & 79.63 \\
\hline condadum & 0.07 & 0.11 & 0.07 & 0.09 & 0.06 & 0.13 \\
\hline condedum & 0.03 & 0.02 & 0.03 & 0.03 & 0.03 & 0.02 \\
\hline condddum & 0.00 & 0.01 & 0.00 & 0.01 & 0.00 & 0.00 \\
\hline perc_no $\sim 1990$ & 17.11 & 16.29 & 16.82 & 17.23 & 17.35 & 15.57 \\
\hline medianvalu $\sim \mathrm{t}$ & $149,319.60$ & $138,515.70$ & $146,399.20$ & $131,916.90$ & $151,841.10$ & $143,546.50$ \\
\hline medttw_int & 22.61 & 22.77 & 22.50 & 22.09 & 22.73 & 23.29 \\
\hline perc_under $\sim \mathrm{t}$ & 26.70 & 26.20 & 26.48 & 25.91 & 26.89 & 26.42 \\
\hline perc_owner $\sim t$ & 72.22 & 74.84 & 71.78 & 75.99 & 72.63 & 73.96 \\
\hline nearestpark & 4.36 & 4.56 & 4.29 & 4.13 & 4.42 & 4.90 \\
\hline nearestsc & 7.88 & 8.86 & 7.72 & 7.45 & 8.05 & 9.93 \\
\hline taxrate & 0.39 & 0.38 & 0.39 & 0.36 & 0.40 & 0.41 \\
\hline post1996 & 0.53 & 0.57 & 0.00 & 0.00 & 1.00 & 1.00 \\
\hline zoneAE_dum & 0.00 & 1.00 & 0.00 & 1.00 & 0.01 & 1.00 \\
\hline zoneX500_dum & 0.00 & 0.00 & 0.00 & 0.00 & 0.01 & 0.00 \\
\hline zoneAE_post & 0.00 & 0.57 & 0.00 & 0.00 & 0.01 & 1.00 \\
\hline zoneX500_post & 0.00 & 0.00 & 0.00 & 0.00 & 0.01 & 0.00 \\
\hline new_sale & 0.29 & 0.26 & 0.30 & 0.25 & 0.27 & 0.28 \\
\hline hydro_ft & $5,500.01$ & $6,007.11$ & $5,409.13$ & $6,271.79$ & $5,584.47$ & $5,805.33$ \\
\hline
\end{tabular}

there nonetheless may still be unobserved spatial heterogeneity that could affect estimates of the impact of the flood disclosure on housing prices. A procedure to address unobserved spatial heterogeneity similar to that used by Black (1999) in her analysis of the value of better schools is used for this application. This is accomplished by changing the "control" group from all the housing observations in the county outside of the X500 and AE zones, to only those observations that are "near" the AE zones. Regressions can then be performed following the specification developed in equation [4] where the housing transactions are limited to those that are within $0.3,0.2$, or 0.1 miles of an AE flood zone boundary. As a final precaution, the standard errors from estimates of equation [4] are clustered at the census tract or block group level. These specifications provide the greatest degree of control for features in time and space that could potentially bias estimates of the impact of 
TABLE 3

Multinomial Logit Test of Comparability of Samples

\begin{tabular}{lccc}
\hline \hline Variables & $\begin{array}{c}\text { AE Zone Pre-Disclosure } \\
(1)\end{array}$ & $\begin{array}{c}\text { AE Zone Post-Disclosure } \\
(2)\end{array}$ & $\begin{array}{c}\text { Chi2 Test that (1) }=(2) \\
(3)\end{array}$ \\
\hline age & $0.011(0.008)$ & $-0.006(0.009)$ & 1.84 \\
Baths & $-0.211(0.264)$ & $0.473(0.179)^{* *}$ & $4.63^{* *}$ \\
acreage & $0.052(0.032)$ & $0.058(0.028)^{* *}$ & 0.03 \\
regheatarea & $0.000(0.000)$ & $0.000(0.000)$ & 0.01 \\
detgarage & $-1.214(1.016)$ & $-0.617(0.724)$ & 0.44 \\
fireplaces & $-0.029(0.306)$ & $-0.302(0.276)$ & $3.78^{*}$ \\
garage & $0.000(0.001)$ & $-0.001(0.001)^{* *}$ & 0.01 \\
new_sale & $0.034(0.300)$ & $0.081(0.256)$ & \\
Constant & $-4.269(0.569)^{* *}$ & $-5.482(0.438)^{* *}$ & 15,514 \\
Number of observations & 15,514 & & \\
\hline
\end{tabular}

Notes: Standard errors are in parentheses. Omitted category are houses not in an AE zone in either the pre-disclosure or post-disclosure time periods.

* Significant at the $10 \%$ level; ** significant at the $5 \%$ level.

flood plain disclosure on housing prices. The next section describes estimated results from this hedonic regression specification.

\section{RESULTS}

\section{Primary Results}

Table 4 presents estimates of the key parameters generated from three hedonic regression specifications. All three specifications use housing transactions that occurred between January 1, 1995 and September 5, 1995 (pre-disclosure time period) and transactions occurring between January 1, 1996 and September 5, 1996 (postdisclosure time period), to avoid the confounding bias of Hurricane Fran and to focus on a limited time span that brackets the start of disclosures on January 1, 1996. Each regression also controls for structural and neighborhood characteristics. Parameter estimates for the structural and neighborhood characteristics were consistent with a priori expectations.

The estimation results reported in column (1) correspond with the specification developed in equation [4] except that the "zoneAE_post" and "zoneX500_post" variables are omitted and the "spatial_dums" are 103 census tract dummy variables. ${ }^{35}$

\footnotetext{
${ }^{35}$ In the 2000 census, there are 104 designated census tracts in Wake County.
}

The estimate on "post1996" is positive and statistically significant suggesting that nominal housing prices have increased by approximately $3 \%$ in Wake County in the year between the two temporal groupings of housing data. ${ }^{36}$ The coefficient on "hydro_ dist" is positive, but not statistically significant. The coefficient on "zoneAE_dum" suggests that houses in the FEMA-designated AE flood zone sold for approximately $2 \%$ less than other comparable homes outside of the flood zone area, but is not statistically significant at conventional levels. It appears there is no price impact on houses located in the X500 flood zone.

Column (2) reports results of a regression that follows the same specification as column (1) with the addition of the "zoneAE_post" and "zoneX500_post" variables. It is important to note that sellers likely marked "yes" on the disclosure statement if their home fell in an AE zone, but were not as likely that they marked "yes" if the home fell in an X500 zone. This is because houses in the X500 zone are not required to purchase insurance and are typically not considered to be a FEMA flood zone although they still pose a flood risk. The

\footnotetext{
${ }^{36}$ These parameter estimates and all other parameter estimates on dummy variables reported in this section have been corrected using the Halvorsen and Palmquist (1980) correction for interpreting dummy variables in semilogarithmic equations.
} 
TABLE 4

Flood Disclosure Regression Results

\begin{tabular}{|c|c|c|c|c|c|c|}
\hline $\begin{array}{l}\text { Dependent } \\
\text { Variable = lprice } \\
\text { Variable }\end{array}$ & $\begin{array}{c}\text { Full } \\
\text { Sample } \\
(1)\end{array}$ & $\begin{array}{c}\text { Full } \\
\text { Sample } \\
(2)\end{array}$ & $\begin{array}{c}\text { Full } \\
\text { Sample } \\
(3)\end{array}$ & $\begin{array}{l}\text { Within } 0.3 \\
\text { Miles of } \\
\text { AE zone } \\
\quad(4)\end{array}$ & $\begin{array}{l}\text { Within } 0.2 \\
\text { Miles of } \\
\text { AE zone } \\
\quad(5)\end{array}$ & $\begin{array}{c}\text { Within } 0.1 \\
\text { Miles of } \\
\text { AE zone } \\
(6)\end{array}$ \\
\hline post1996 & $\begin{array}{l}0.028 \\
(0.003)^{* *}\end{array}$ & $\begin{array}{l}0.028 \\
(0.004)^{* *}\end{array}$ & $\begin{array}{l}0.027 \\
(0.006)^{* *}\end{array}$ & $\begin{array}{l}0.045 \\
(0.009)^{* *}\end{array}$ & $\begin{array}{l}0.049 \\
(0.011)^{* *}\end{array}$ & $\begin{array}{l}0.038 \\
(0.014)^{* *}\end{array}$ \\
\hline hydro_dist & $\begin{array}{c}0.015 \\
(0.014)\end{array}$ & $\begin{array}{c}0.015 \\
(0.014)\end{array}$ & $\begin{array}{c}0.011 \\
(0.013)\end{array}$ & $\begin{array}{c}0.006 \\
(0.016)\end{array}$ & $\begin{array}{c}0.017 \\
(0.019)\end{array}$ & $\begin{array}{c}0.036 \\
(0.029)\end{array}$ \\
\hline zoneAE_dum & $\begin{array}{r}-0.020 \\
(0.013)\end{array}$ & $\begin{array}{c}0.005 \\
(0.014)\end{array}$ & $\begin{array}{c}0.003 \\
(0.015)\end{array}$ & $\begin{array}{c}0.012 \\
(0.014)\end{array}$ & $\begin{array}{l}0.007 \\
(0.014)\end{array}$ & $\begin{array}{c}0.010 \\
(0.016)\end{array}$ \\
\hline zoneX500_dum & $\begin{array}{c}0.010 \\
(0.016)\end{array}$ & $\begin{array}{c}0.027 \\
(0.025)\end{array}$ & $\begin{array}{c}0.029 \\
(0.023)\end{array}$ & $\begin{array}{c}0.038 \\
(0.025)\end{array}$ & $\begin{array}{c}0.021 \\
(0.027)\end{array}$ & $\begin{array}{c}0.016 \\
(0.022)\end{array}$ \\
\hline zoneAE_post & & $\begin{array}{l}-\mathbf{0 . 0 4 3} \\
(0.022)^{* *}\end{array}$ & $\begin{array}{c}-\mathbf{0 . 0 4 2} \\
(0.023)^{*}\end{array}$ & $\begin{array}{c}-\mathbf{0 . 0 5 3} \\
(0.025)^{* *}\end{array}$ & $\begin{array}{l}-\mathbf{0 . 0 5 2} \\
(0.026)^{* *}\end{array}$ & $\begin{array}{c}-\mathbf{0 . 0 4 8} \\
(0.028)^{*}\end{array}$ \\
\hline zoneX500_post & & $\begin{array}{c}-0.027 \\
(0.031)\end{array}$ & $\begin{array}{c}-0.016 \\
(0.029)\end{array}$ & $\begin{array}{c}-0.029 \\
(0.029)\end{array}$ & $\begin{array}{c}-0.027 \\
(0.029)\end{array}$ & $\begin{array}{r}-0.030 \\
(0.028)\end{array}$ \\
\hline Constant & $\begin{array}{l}10.851 \\
(0.074)^{* *}\end{array}$ & $\begin{array}{l}10.850 \\
(0.074)^{* *}\end{array}$ & $\begin{array}{l}11.485 \\
(0.247)^{* *}\end{array}$ & $\begin{array}{l}11.583 \\
(0.224)^{* *}\end{array}$ & $\begin{array}{l}11.626 \\
(0.232)^{* *}\end{array}$ & $\begin{array}{l}11.585 \\
(0.357)^{* *}\end{array}$ \\
\hline $\begin{array}{c}\text { Census tract } \\
\text { dummies }\end{array}$ & $\mathrm{X}$ & X & & & & \\
\hline $\begin{array}{l}\text { Block group } \\
\text { dummies }\end{array}$ & & & $\mathrm{X}$ & $\mathrm{X}$ & $\mathrm{X}$ & $\mathrm{X}$ \\
\hline $\begin{array}{l}\text { Structural and } \\
\text { neighborhood } \\
\text { controls }\end{array}$ & $\mathrm{X}$ & $\mathrm{X}$ & $\mathrm{X}$ & $\mathrm{X}$ & $\mathrm{X}$ & $\mathrm{X}$ \\
\hline $\begin{array}{l}\text { Clustering at } \\
\text { census tract }\end{array}$ & $\mathrm{X}$ & $\mathrm{X}$ & & & & \\
\hline $\begin{array}{l}\text { Clustering at } \\
\text { block group }\end{array}$ & & & $\mathrm{X}$ & $\mathrm{X}$ & $\mathrm{X}$ & $\mathrm{X}$ \\
\hline $\begin{array}{l}\text { Number of } \\
\text { spatial } \\
\text { dummies }\end{array}$ & 104 & 104 & 253 & 207 & 192 & 163 \\
\hline $\begin{array}{l}\text { Number of } \\
\text { observations }\end{array}$ & 15,514 & 15,514 & 15,514 & 6,243 & 4,253 & 2,136 \\
\hline$R^{2}$ & 0.92 & 0.92 & 0.92 & 0.93 & 0.93 & 0.93 \\
\hline
\end{tabular}

Notes: Robust clustered standard errors are in parentheses. The boldface type in the "zoneAE_post" row highlights the primary result. * Significant at the $10 \%$ level; ** significant at the $5 \%$ level.

coefficient on "zoneAE_post" suggests that the disclosure did impact housing prices in the flood zone by approximately $4.3 \%$. The coefficient on "zoneAE_dum" in column (2) is approximately zero and insignificant suggesting that all of the negative impact of the AE flood zone on housing prices that was estimated in column (1) is due to houses that sold in the January 1, 1996 to September 5, 1996 time period. Although the parameter estimate on "zoneX500 post" is negative, it is statistically insignificant. The estimates for "post1996," "hydro_dist," as well as the estimates for other structural and neighborhood characteristics are virtually unchanged between columns (1) and (2).
As a check on the sensitivity of the estimates reported in column (2) to the census tract dummies used as spatial controls, column (3) re-estimates the same specification but in this case includes 252 block-group dummy variables instead of the census tract dummies. ${ }^{37}$ If the estimate on "zoneAE_post" was weakened due to disaggregating the spatial fixed effects from 104 (census tracts) to 253 (block-group) zones, then this change would cause concern about the identification strategy. However, as can be seen in Table 4 the estimate

\footnotetext{
${ }^{37}$ In the 2000 census, there are 253 designated blockgroups in Wake County.
} 
for "zoneAE_post" is essentially the same and other coefficients are also stable.

Columns (4)-(6) present estimates from the same specification as column (3) except that housing transactions are limited to those that are within $0.3,0.2$, or 0.1 miles of an AE flood zone boundary in an effort to control for omitted spatial heterogeneity. The estimate on "zoneAE_post" in these regressions is basically unchanged. The estimate corresponding to the most restrictive zone is given in column (6). In this case only housing transactions within a tenth of a mile are used as the control group to the X500 and AE zones. These results suggest a $4.9 \%$ decrease in housing prices in the $\mathrm{AE}$ zone after the flood zone disclosure.

\section{Discussion and Comparison of Results with Flood Insurance Costs}

In Section 2, it was argued that when the fraction of uninformed buyers for a housing attribute is non-trivial, estimates of the marginal value of an attribute generated from a hedonic price regression will likely be attenuated relative to a "full information" environment. The results from this analysis suggest that the fraction of uninformed buyers was substantial prior to the flood plain disclosure. The flood plain disclosure likely caused buyers to pay attention to flood risk and reduced the costs of acquiring flood risk information and of learning if a house was in a FEMA flood zone. The housing price impact after sellers were required to provide a disclosure about FEMA flood zones, is consistent with the hypothesized effect of asymmetric information between buyers and sellers. Prior to the disclosure the price impact of a house in an AE flood plain was approximately zero, afterwards the estimate was in the range of $3.8 \%$ to $4.5 \%$ (percentages are derived by adding the coefficients on the "zoneAE_dum" and "zoneAE_post" variables). This corresponds with the large hypothesized shift that was illustrated in Figure 4 for houses with a high level of the disamenity $\left(z_{H i g h}{ }^{j}\right)$. This post-disclosure estimate may be a closer approximation to the "true" value to avoid flood zones when there is full information in the housing market.

The estimated price impact of $3.8 \%$ to $4.5 \%$ to avoid the AE flood plain represents a price discount in the range of $\$ 5,434$ to $\$ 6,435$ for an average priced house in an AE zone. $^{38}$ To put this price discount in context, information on typical flood insurance rates during the 1996 time period was gathered. FEMA produces detailed flood insurance manuals to help those that write flood insurance policies. A host of variables enter into a flood insurance rate for a given house such as (1) whether or not the structure was built before or after the flood insurance rate maps were established for the area (called Pre-FIRM and Post-FIRM properties), (2) the structures elevation in relation to the base flood elevation, and (3) whether or not there is an enclosure at the base of the property or other built-in flood mitigators.

Abstracting from the multitude of factors that determine a flood insurance rate, an approximation of insurance rates can be obtained using sample flood insurance rates for a "typical house" provided by FEMA. The rates are for flood insurance coverage of a house valued at $\$ 100,000$ and $\$ 25,000$ of contents. The annual policy costs in 1996 for a PostFIRM house in the North Carolina Region, in an $\mathrm{AE}$ zone, whose elevation of its lowest floor is three feet above the base flood elevation estimated by FEMA, was \$211.00. ${ }^{39}$ The annual policy cost for the same house whose lowest floor is one foot below the base flood elevation is $\$ 1,114.50$. The present value of these two policies assuming a $6 \%$ discount rate in perpetuity is $\$ 3,517$ and $\$ 18,575$ respectively. Therefore, the estimated flood insurance risk premium of $\$ 5,434$ to $\$ 6,435$ falls on the lower end of

\footnotetext{
${ }^{38}$ The average priced house in an $\mathrm{AE}$ zone was $\$ 143,000$.

39 These dollar amounts are in 1996 dollars. Historical flood insurance rates are extremely difficult to acquire. I am indebted to Philip Letsinger of the North Carolina Floodplain Management Branch for finding and providing me with these historical sample flood insurance rates.
} 
the flood insurance cost range, but appears to be reasonable.

\section{CONCLUSION}

The hedonic method has been described as "one of the 'success stories' of modern applied micro-economic analysis" (Palmquist and Smith 2002). It has indeed been a highly influential method within the profession of environmental economics and for environmental public policy. With the increased availability of high quality real estate data and GIS information on environmental attributes throughout the United States, there is reason to believe that the hedonic method will continue to be widely applied to understand a variety of non-market valuation type problems. However, as this study points out, the accuracy of these hedonic analyses (especially for environmental disamenities) are partially tied to how well the assumption that buyers are fully informed is satisfied. Asymmetric information between buyers and sellers will likely influence estimated implicit prices and whether they can be interpreted as marginal values.

To better understand the impact of asymmetric information on the implicit prices estimated from the hedonic method, this study used a flood plain disclosure as a quasi-random experiment. The disclosure provided by sellers likely caused buyers to pay attention and become informed about the flood risks associated with a property. Using housing data that symmetrically bracketed the disclosure time period but omitted transactions that would have been impacted by a recent hurricane, it was estimated that the disclosure reduced housing prices in FEMA-designated AE zones by approximately $4 \%$. When compared with the costs of insuring properties in these flood prone areas, this range of estimates appears reasonable.

These results support the graphical intuition of the impact of asymmetric information on the implicit price of a disamenity developed in Section 2. They also suggest that a simple information disclosure that re-provides information that is already publicly available, can impact housing prices contrary to what would be predicted by the conventional hedonic model that assumes that buyers and sellers are "fully informed." The results have important implications for both the National Flood Insurance Program and flood-prone properties. They suggest that there may be serious inefficiencies in the housing market as related to flood risk. Developed properties in flood zones may not be sufficiently discounted when a significant fraction of buyers remain uninformed. This may also provide a perverse incentive for developers to develop flood prone properties and sell developed properties for a profit.

An important point of this study is that simply placing environmental information in the public domain does not guarantee that the information will be noticed and used by economic agents. Search costs including cognitive costs can leave some economic agents uninformed. However, the results should not be interpreted as overly negative towards the hedonic method. Carefully crafted hedonic studies certainly provide useful information to policymakers about how households value certain types of environmental attributes of real property. However, as this study points out, part of carefully crafting a hedonic analysis requires understanding the information environment in which buyers and sellers perform their transactions. Quasi-random information experiments and housing data provide new opportunities to refine our understanding of non-market values.

\section{References}

Bin, Okmyung, and Stephen Polasky. 2004. "Effects of Flood Hazards on Property Values: Evidence Before and After Hurricane Floyd." Land Economics 80 (Nov.): 490-500.

Black, Sandra E. 1999. "Do Better Schools Matter? Parental Valuation of Elementary Education." 
Quarterly Journal of Economics 114 (2): 57799.

Cameron, T. A. 2006. "Directional Heterogeneity in Distance Profiles in Hedonic Property Value Models." Journal of Environmental Economics and Management 51 (1): 26-45.

Chay, Kenneth Y., and Michael Greenstone. 2005. "Does Air Quality Matter? Evidence from the Housing Market." Journal of Political Economy 113 (2): 376-424.

Chivers, James, and Nicholas E. Flores. 2002. "Market Failure in Information: The National Flood Insurance Program." Land Economics 78 (Nov.): 515-21.

Cropper, M. L., L. Deck, and K. E. McConnell. 1988. "On the Choice of Functional Forms for Hedonic Price Functions." Review of Economics and Statistics 70 (4): 668-75.

Gayer, Ted, James Hamilton, and W. Kip Viscusi. 2000. "Private Values of Risk Tradeoffs at Superfund Sites: Housing Market Evidence on Learning about Risk." Review of Economics and Statistics 82 (3): 439-51.

Geoghegan, J., L. A. Wainger, and N. E. Bockstael. 1997. "Spatial Landscape Indices in a Hedonic Framework: An Ecological Economics Analysis using GIS." Ecological Economics 23 (3): 251-64.

Hallstrom, Daniel G., and V. Kerry Smith. 2005. "Market Responses to Hurricanes." Journal of Environmental Economics and Management 50 (3): 541-61.

Halvorsen, R., and R. Palmquist. 1980. "The Interpretation of Dummy Variables in Semilogarithmic Equations." American Economic Review 70 (3): 474-75.

Harding, J. P., S. R. Rosenthal, and C. F. Sirmans. 2003. "Estimating Bargaining Power in. the Market for Existing Homes." Review of Economics and Statistics 85 (1): 178-88.

Holoway, James M., and Raymond Burby. 1990. "The Effects of Floodplain Development Controls on Residential Land Values." Land Economics 66 (Aug.): 259-70.

Kiel, Katherine, and Katherine McClain. 1995. "House Prices during Siting Decision Stages: The Case of an Incinerator from Rumor through Operation." Journal of Environmental Economics and Management 28 (2): 241-55.

King, Rawle O. 2005. "Federal Flood Insurance: The Repetitive Loss Problem." CRS Report for Congress. Order Code RL32972.

Krutilla, John V. 1966. "An Economic Approach to Coping with Flood Damage." Water Resources Research 2 (2): 183-90.
Kumbhakar, Subal C., and Christopher F. Parmeter. 2006. "Estimation of Hedonic Price Functions with Incomplete Information." Working paper number 2008-64, Department of Agricultural and Applied Economics, Virginia Tech.

Lefcoe, G. 2004. "Property Condition Disclosure Forms: How the Real Estate Industry Eased the Transition from Caveat Emptor to "Seller Tell All"." Real Property, Probate and Trust Journal 39 (Summer): 193-250.

Leggett, C. G., and N. E. Bockstael. 2000. "Evidence of the Effects of Water Quality on Residential Land Prices." Journal of Environmental Economics and Management 39 (2): $121-44$.

McCluskey, Jill, and Gordon C. Rausser. 2003. "Estimation of Perceived Risk and Its Effect on Property Values." Land Economics 77 (Feb.): 42-55.

Meyer, Bruce D. 1995. "Natural and QuasiExperiments in Economics." Journal of Business and Economic Statistics 13 (2): 151-61.

Muckleston, K. W. 1983. "The Impact of Floodplain Regulations on Residential Land Values in Oregon." Water Resources Bulletin 19 (1): $1-7$.

Palmquist, R. B. 2005. "Property Value Models." Handbook of Environmental Economics, ed. Karl-Göran Mäler and Jeffery R. Vincent. Amsterdam: North-Holland.

Palmquist, R. B., and V. K. Smith. 2002. "The Use of Hedonic Property Value Techniques for Policy and Litigation." In The International Yearbook of Environmental and Resource Economics 2002/2003, ed. T. Tietenberg and H. Folmer, 115-64. Cheltenham, U.K.: Edward Elgar.

Pope, Jaren C. 2008. "Buyer Information and the Hedonic: The Impact of a Seller Disclosure on the Implicit Price for Airport Noise." Journal of Urban Economics 63 (2): 498-516.

Ridker, Ronald G., and John A. Henning. 1967. "The Determinants of Residential Property Values with Special Reference to Air Pollution." Review of Economics and Statistics 49 (May): 246-57.

Rosen, R. 1974. "Hedonic Prices and Implicit Markets: Product Differentiation in Pure Competition." Journal of Political Economy 82 (1): 34-55.

Rowe, R. D., and W. D. Schulze. 1985. "Economic Assessment of Damage Related to the Eagle Mine Facility." Denver: Energy and Resource Consultants, Inc.

Schulze, W., G. McClelland, B. Hurd, and J. Smith. 1986. "A Case Study of Hazardous 
Waste Site: Perspectives from Economics and Psychology." Draft report. Contract CR812054-01-1. Washington, D.C.: U.S. Environmental Protection Agency.

Smith, V. K., and J. C. Huang. 1995. "Can Markets Value Air Quality? A Meta-Analysis of Hedonic Property Value Models." Journal of Political Economy 103 (1): 209-27.

Speyrer, J., and W. Ragas. 1991. "Housing Prices and Flood Risk: An Examination Using Spline
Regression." Journal of Real Estate Finance and Economics 4 (4): 395-407.

Tobin, G. A., and B. E. Montz. 1994. "The Flood Hazard and Dynamics of the Urban Residential Land Market." Water Resources Bulletin 30 (4): 673-85.

U.S. General Accounting Office (GAO). 2003. "Challenges Facing the National Flood Insurance Program." GAO Report GAO-03-606T, p. 16. Washington, D.C. 